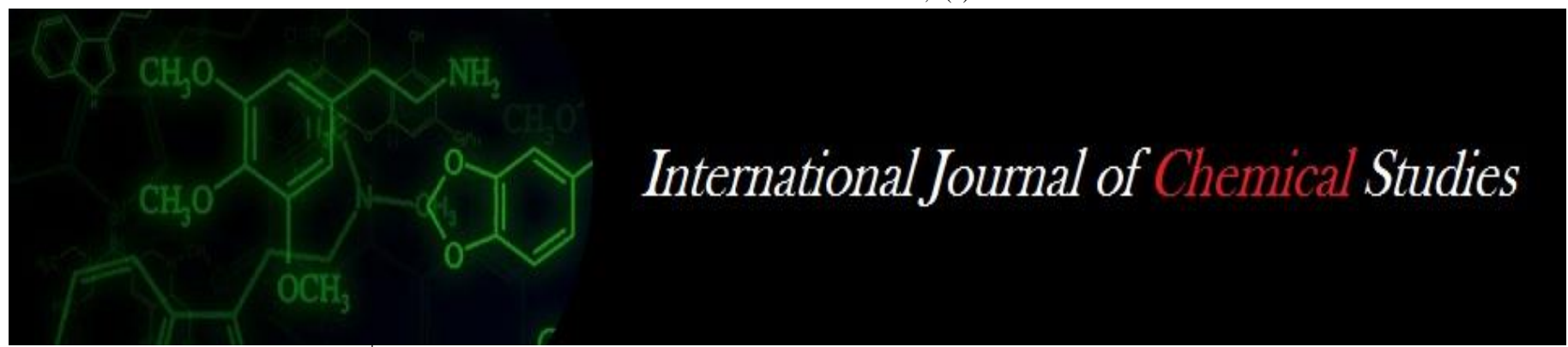

P-ISSN: 2349-8528

E-ISSN: 2321-4902

www.chemijournal.com

IJCS 2021; 9(1): 709-712

(C) 2021 IJCS

Received: 21-11-2020

Accepted: 30-12-2020

\section{PB Gunjal}

PG. Student, Department of

Agronomy, Agronomy Section,

R.C.S.M. College of Agriculture,

Kolhapur, Maharashtra, India

\section{AB Mohite}

Associate Professor, Department

of Agronomy, Agronomy

Section, R.C.S.M. College of

Agriculture, Kolhapur,

Maharashtra, India

\section{JB Patil}

Assistant Professor, Department

of Agronomy, Agronomy

Section, R.C.S.M. College of

Agriculture, Kolhapur,

Maharashtra, India

\section{VB Gedam}

Assistant Professor, Department

of Agronomy, Agronomy

Section, R.C.S.M. College of

Agriculture, Kolhapur,

Maharashtra, India

\section{Effect of land configuration methods and sulphur levels on yield attributes, quality and yield of soybean (Glycine max L. Merrill)}

\author{
PB Gunjal, AB Mohite, JB Patil and VB Gedam
}

DOI: https://doi.org/10.22271/chemi.2021.v9.i1j.11310

\begin{abstract}
The field experiment was conducted during kharif season of 2019-20 on medium black soil to study the effect of different land configuration methods and sulphur levels and their interaction at post graduate research farm, R.C.S.M. College of Agriculture, Kolhapur(MS). The treatment was conducted in split plot design with three replication and sixteen treatment comprising of four land configuration methods viz., $\mathrm{I}_{1}$ - flat bed, $\mathrm{I}_{2}-\mathrm{BBF}, \mathrm{I}_{3}$ - ridge and furrow ( 2 feet), $\mathrm{I}_{4}$ - ridge and furrow ( 3 feet) and four sulphur levels viz., $\mathrm{S}_{1}-00 \mathrm{~kg} \mathrm{ha}^{-1}, \mathrm{~S}_{2}-10 \mathrm{~kg} \mathrm{ha}^{-1}, \mathrm{~S}_{3}-20 \mathrm{~kg} \mathrm{ha}^{-1}, \mathrm{~S}_{4}-30 \mathrm{~kg} \mathrm{ha}^{-1}$ in subplots. The yield and quality attributes like number of pods plant ${ }^{-1}$, length of podsplant ${ }^{-1}$, weight of pods plant ${ }^{-1}$, number of seeds pods 1 , weight of seeds plant ${ }^{-1}, 100$ seeds weight, oil and protein content as well as yield was also found maximum with the land configuration method ridge and furrow ( 3 feet) however it was comparable with the method BBF. As a result, the land configuration method ridge and furrow (3 feet) had the highest seed and stover yields as well as oil and the protein content were found maximum in the method ridge and furrow (3 feet). The yield and quality attributes were also highest and influenced significantly by application of $30 \mathrm{Kg} \mathrm{S} \mathrm{ha}^{-1}$ but on par with $20 \mathrm{Kg} \mathrm{S} \mathrm{ha}^{-1}$. As a result the application of $30 \mathrm{Kg} \mathrm{S} \mathrm{ha}^{-1}$ had the highest seed and stover yields. Also the oil and the protein content were found maximum in the treatment applied $30 \mathrm{Kg} \mathrm{S} \mathrm{ha}^{-1}$ but comparable with $20 \mathrm{Kg} \mathrm{S} \mathrm{ha}^{-1}$.
\end{abstract}

Keywords: Land configuration methods, sulphur levels, yield, quality, soybean

\section{Introduction}

Soybean (Glycine max L. Merrill) is known as Chinese pea and Manchurian bean belongs to family leguminosae. Soybean crop is rich source of quality protein (40-42\%), oil (18-20\%) and other nutrients viz. calcium, magnesium and iron and glycine. It is a good source of isoflavones and therefore, it helps in preventing heart diseases, cancer and HIVs. Industrial uses of oil are in soap, paints, resins, and drying oil. A number of protein rich product, soyamilk, soya-paneer (tofu), soy-sauce, and soy-flour are produced from seeds. (Balasubramaniyan \& Palaniappan, 2012) ${ }^{[3]}$. Soybean is an important oilseed crop in the world and gaining importance in India and is considered as golden bean. India has revolutised the rural economy and improved socio economic status of farmers in Madhya Pradesh, Maharashtra and Rajasthan since last five years as it plays major role in the global oilseed economy having $59 \%$ share of total oilseed production. Its contribution is around $35 \%$ of our oilseed production. Soybean has spread to different countries in the world and became an established component of world agriculture. Soybean has not only gained a vital importance in Indian Agriculture, but also plays a decisive role in oil economy of India. Soybean is known as wonder crop and it occupied a significant position in cropping systems of Western Maharashtra region. Hence its cultivation with various land configurations and sulphur levels plays important to improve its productivity and yield potential.Due to alteration of different land configuration the high and economical yield obtained because of these alteration provide the suitable microclimate for root growth and development, microorganism development, conserving soil moisture, increment in the uptake of plant nutrient and also provide support to plant stand in abnormal condition like high rainfall and high wind speed during the abnormal climatic conditions. Low productivity of soybean may be due to the nutritional deficiencies and also imbalanced fertilization. Ideal N: P: K ratio as 4:2:1 and accepted for macro level monitoring of consumption of plant nutrients for a country as a whole.
Corresponding Author: JB Patil

Assistant Professor, Department of Agronomy, Agronomy Section, R.C.S.M. College of Agriculture, Kolhapur,

Maharashtra, India 
However, it is difficult to trace the genesis of this NPK ratio, whereas Indian soil ratio is 6.8:2.7:1. Sulphur plays an important role in improving the quality and marketability of produce. On an average, the improvement on oil content in major oilseeds due to sulphur application is 11.3 per cent in groundnut, 9.6 per cent in mustard, 9.2 per cent in soybean. In general, 15-50 percent increase in oil yield has been reported by Pasricha and Aulakh (1996) ${ }^{[15]}$. Sulphur also plays a crucial role in fat and protein metabolism.

\section{Materials and Methods}

The field experiment was conducted at Post Graduate Research Farm, R.C.S.M. College of Agriculture, and Kolhapur during Kharif 2019. The topography of experimental field was fairly uniform and leveled. The soil was vertisol (medium black) in nature and about one meter deep with good drainage. The soil of experimental field has $\mathrm{pH} 7.70, \mathrm{EC} 0.30 \mathrm{dSm}^{-1}$, organic carbon $0.18 \%$, available $\mathrm{N}$, $\mathrm{P}_{2} \mathrm{O}_{5}, \mathrm{~K}_{2} \mathrm{O}, \mathrm{S}$ was $207.10,28.80,287.10$ and $16.84 \mathrm{~kg}$ ha ${ }^{1}$,respectively. The sixteen treatment combinations consist of four land configuration methods viz., $\mathrm{I}_{1}$ - flat bed, $\mathrm{I}_{2}$ - broad bed furrow, $\mathrm{I}_{3}$ - ridges and furrow ( 2 feet), $\mathrm{I}_{4}$ - ridges and furrow (3 feet), and four sulphur levels viz., $S_{1}\left(00 \mathrm{~kg} \mathrm{Sha}^{-1}\right)$, $\mathrm{S}_{2}\left(10 \mathrm{~kg} \mathrm{~S} \mathrm{ha}^{-1}\right), \mathrm{S}_{3}\left(30 \mathrm{~kg} \mathrm{Sha}^{-1}\right)$ and $\mathrm{S}_{4}\left(40 \mathrm{~kg} \mathrm{~S} \mathrm{ha}^{-1}\right)$ and these treatments were replicated three times in split plot design. Soybean was grown on different land configuration methods and sulphur applied as per treatments in the experimental field with recommended package of practices. Fertilizers were applied uniformly at the rate of $50 \mathrm{~kg} \mathrm{~N}$ and $75 \mathrm{~kg} \mathrm{P}_{2} \mathrm{O}_{5}$ and $45 \mathrm{~kg} \mathrm{~K}_{2} \mathrm{O} \mathrm{ha}^{-1}$ by broadcasting method at the time of sowing and sulphur applied as per dose 15 days before the sowing of crop. The experimental data was statistically analyzed by using a standard method of "analysis of variance" as reported by Panse and Sukhatme (1967) ${ }^{[14]}$.

\section{Result and Discussion \\ Effect on yield parameters \\ Effect of land configurations}

The different yield attributing characters as influenced by different treatment were presented in Table No 1. The significantly highest values under land configuration method i.e. 3 feet ridge and furrow of all growth characters viz. number of pods plant ${ }^{-1}$, length of pods plant ${ }^{-1}$, weight of pods plant $^{-1}$, number of seeds pod ${ }^{-1}$, weight of seeds plant ${ }^{-1}$ and 100 seeds weight at harvest were recorded, however it was comparable with the land configuration method i.e. Broad Bed furrow. Both these land methods are significantly superior over other methods viz., 2 feet ridge and furrow and flat bed. The results of field experiment showed better performance under ridges and furrow layouts than other layouts under study. (Thakur et al., 2003; Ingle et al.,1999; Lakpale and Tripathi 2012; and Nangare 2015) ${ }^{[16,10,12,13]}$.

\section{Effect of sulphur levels}

The different yield attributing characters as influenced by different treatment were presented in Table No 1. Application of $30 \mathrm{~kg} \mathrm{~S} \mathrm{ha}{ }^{-1}$ recorded significantly the highest mean number of pods plant ${ }^{-1}$, length of pods plant ${ }^{-1}$, weight of pods plant $^{-1}$, number of seeds pod ${ }^{-1}$, weight of seeds plant ${ }^{-1}$ and 100 seeds weight as compared to rest of the sulphur levels, however comparable with $20 \mathrm{~kg} \mathrm{~S}^{-1}$ at the time of harvest. The mean number of pods plant ${ }^{-1}$, weight of pods plant ${ }^{-1}$, number of seeds pod ${ }^{-1}$, weight of seeds plant ${ }^{-1}$ and 100 seeds weight increased with increasing levels of sulphur and reached maximum with $30 \mathrm{~kg} \mathrm{~S} \mathrm{ha}{ }^{-1}$. The increasing rate of soil application of sulphur to $\mathrm{S}$ deficient soil must have increased the number of pods plant ${ }^{-1}$ (Devi et al., 2012) ${ }^{[4]}$.

\section{Effect of interaction}

The interaction effect between land configuration methods and sulphur methods were found to be non-significant in respect of different yield attributing characters.

\section{Effect on yield}

\section{Effect of land configuration methods}

The mean seed yield, stover yields and harvest index of as influenced by different treatments presented in Table No 2 reveled that among the land configuration methods the field layout i.e. 3 feet ridge and furrow produced maximum mean seed yield, stover yield and harvest index at the time of harvest and found significantly superior over the treatments 2 feet ridge and furrow and flat bed, however comparable with the land configuration method broad bed furrow at harvest. However Nangare (2015) ${ }^{[13]}$ recorded increased seed yield, stover yields and harvest index in soybean under ridge and furrow planting over flatbed method of planting.

Effect of sulphur levels: The different yield attributing characters as influenced by different treatment were presented in Table No 2. Application of $30 \mathrm{~kg} \mathrm{~S} \mathrm{ha}^{-1}$ recorded the highest mean seed yield, stover yields and harvest index as compared to rest of the sulphur levels, however but on par with sulphur fertilization@ $20 \mathrm{~kg} \mathrm{ha}^{-1}$ after harvest and significantly superior over $10 \mathrm{~kg} \mathrm{~S} \mathrm{ha}^{-1}$ and $00 \mathrm{~kg} \mathrm{ha}^{-1}$. Mean seed yield, stover yields and harvest index increased with increasing each levels of sulphur. The sulphur fertilization played a vital role in improving the three major aspects of yield determination i.e. formation of vegetative structure there by photosynthesis strong sink strength through development of reproductive structure and production of assimilates to fill economically important sink. Thus cumulative influence of $S$ application maintained balance in source-sink relationship and ultimately resulted in increased seed yield. The results are in close conformity with the findings of Ganeshmurthy et al., (1996) ${ }^{[5]}$ and Hussain et al., (2011) ${ }^{[9]}$.

Table 1: Effect of land configuration methods and sulphur levels on yield parameters of soybean at harvest

\begin{tabular}{|c|c|c|c|c|c|c|}
\hline Treatments & $\begin{array}{c}\text { Number of } \\
\text { pods plant }\end{array}$ & $\begin{array}{l}\text { Length of pods } \\
\text { plant }^{-1}(\mathrm{~cm})\end{array}$ & $\begin{array}{c}\text { Weight of pods } \\
\text { plant }^{-1}(\mathrm{~g})\end{array}$ & $\begin{array}{c}\text { Number of seeds } \\
\text { pod }^{-1}\end{array}$ & $\begin{array}{c}\text { Weight of seeds } \\
\text { plant }^{-1}(\mathrm{~g})\end{array}$ & $\begin{array}{l}100 \text { seeds } \\
\text { weight }(\mathrm{g})\end{array}$ \\
\hline \multicolumn{7}{|c|}{ Main Plot: land configurations } \\
\hline $\mathrm{I}_{1}$ - Flat Bed & 54.75 & 2.31 & 25.02 & 2.30 & 16.16 & 11.94 \\
\hline $\mathrm{I}_{2}$ - Broad Bed Furrow & 70.78 & 2.51 & 32.22 & 2.88 & 23.18 & 13.04 \\
\hline 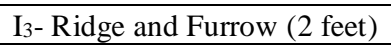 & 61.50 & 2.45 & 25.60 & 2.38 & 16.85 & 12.15 \\
\hline I4- Ridge and Furrow (3 feet)) & 70.90 & 2.63 & 32.57 & 2.91 & 24.13 & 13.13 \\
\hline S. Em \pm & 2.03 & 0.05 & 0.87 & 0.07 & 0.48 & 0.23 \\
\hline C. D. at $5 \%$ & 7.02 & 0.18 & 3.00 & 0.25 & 1.66 & 0.81 \\
\hline C. V.\% & 10.9 & 7.28 & 10.40 & 9.5 & 8.28 & 6.44 \\
\hline \multicolumn{7}{|c|}{ Sub Plot: Sulphur levels } \\
\hline
\end{tabular}




\begin{tabular}{|c|c|c|c|c|c|c|}
\hline $\mathrm{S}_{1}-00 \mathrm{Kg} \mathrm{S} \mathrm{ha}{ }^{-1}$ & 59.96 & 2.18 & 26.42 & 2.42 & 17.55 & 11.88 \\
\hline$S_{2}-10 \mathrm{Kg} \mathrm{S} \mathrm{ha}^{-1}$ & 62.47 & 2.45 & 26.84 & 2.53 & 19.35 & 12.16 \\
\hline$S_{3}-20 \mathrm{Kg} \mathrm{S} \mathrm{ha}^{-1}$ & 66.42 & 2.55 & 29.28 & 2.73 & 21.31 & 13.03 \\
\hline $\mathrm{S}_{3}-30 \mathrm{Kg} \mathrm{S} \mathrm{ha}^{-1}$ & 69.07 & 2.73 & 32.15 & 2.78 & 22.37 & 13.19 \\
\hline S. EM \pm & 1.87 & 0.06 & 0.86 & 0.08 & 0.47 & 0.25 \\
\hline C. D. at $5 \%$ & 5.49 & 0.18 & 2.50 & 0.23 & 1.38 & 0.72 \\
\hline C. V.\% & 10.10 & 8.84 & 10.29 & 10.4 & 8.18 & 6.78 \\
\hline \multicolumn{7}{|c|}{ Interaction: $\mathbf{I} \times \mathbf{S}$} \\
\hline S. EM \pm & 3.76 & 0.13 & 1.71 & 0.16 & 0.95 & 0.49 \\
\hline C. D. at $5 \%$ & NS & NS & NS & NS & NS & NS \\
\hline General mean & 64.48 & 2.47 & 28.85 & 2.62 & 20.08 & 12.56 \\
\hline
\end{tabular}

Table 2: Effect of land configuration methods and sulphur levels on yield of soybean after harvest

\begin{tabular}{|c|c|c|c|}
\hline Treatments & Seed yield $\left(q h^{-1}\right)$ & Stover yield $\left(\mathrm{q} \mathrm{ha}^{-1}\right)$ & Harvest Index (\%) \\
\hline \multicolumn{4}{|c|}{ Main Plot: land configurations } \\
\hline $\mathrm{I}_{1}$ - Flat Bed & 21.05 & 31.59 & 39.80 \\
\hline I2- Broad Bed Furrow & 26.09 & 38.51 & 40.34 \\
\hline I3- Ridge and Furrow (2 feet) & 23.63 & 35.71 & 39.85 \\
\hline I4- Ridge and Furrow (3 feet)) & 26.63 & 39.55 & 40.40 \\
\hline S. EM \pm & 0.80 & 0.85 & 1.32 \\
\hline C. D. at $5 \%$ & 2.78 & 2.94 & NS \\
\hline C. V.\% & 11.43 & 8.11 & 11.47 \\
\hline \multicolumn{4}{|c|}{ Sub Plot: Sulphur levels } \\
\hline $\mathrm{S}_{1-00 \mathrm{Kg} \mathrm{S} \mathrm{ha}}{ }^{-1}$ & 22.57 & 34.05 & 37.31 \\
\hline $\mathrm{S}_{2}-10 \mathrm{Kg} \mathrm{S} \mathrm{ha}^{-1}$ & 24.28 & 35.77 & 40.64 \\
\hline $\mathrm{S}_{3}-20 \mathrm{Kg} \mathrm{S} \mathrm{ha}^{-1}$ & 25.39 & 36.68 & 40.99 \\
\hline $\mathrm{S}_{3}-30 \mathrm{Kg} \mathrm{S} \mathrm{ha}^{-1}$ & 27.17 & 38.85 & 41.46 \\
\hline S. EM \pm & 0.76 & 1.08 & 1.01 \\
\hline C. D. at $5 \%$ & 2.24 & 3.14 & 2.95 \\
\hline C. V.\% & 10.91 & 10.26 & 8.73 \\
\hline \multicolumn{4}{|c|}{ Interaction: $\mathbf{I} \times \mathbf{S}$} \\
\hline S. EM \pm & 1.53 & 2.15 & 2.02 \\
\hline C. D. at $5 \%$ & NS & NS & NS \\
\hline General mean & 24.35 & 36.34 & 40.10 \\
\hline
\end{tabular}

Hosmath et al., (2014) ${ }^{[8]}$ reported that sulphur is an important nutrient for the higher yield of soybean crop. Arun Sharma (2011) [2] documented that when supply of sulphur is optimum, greater translocation of photosynthats occurs from leaves to seed.

\section{Effect of interaction}

The interaction effect between land configuration methods and sulphur methods were found to be non-significant in respect of different parameters of yield.

\section{Effect on quality}

\section{Effect of land configuration methods}

The mean oil content $(18.67 \%)$, protein content $(42.41 \%)$, oil yield $\left(4.97 \mathrm{~kg} \mathrm{ha}^{-1}\right)$ and protein yield $\left(11.33 \mathrm{~kg} \mathrm{ha}^{-1}\right)$ differed significantly due to different land configuration methods as influenced by different treatments presented in Table No 2. The land configuration method 3 feet ridge and furrow produced maximum mean oil content, protein content, oil yield and protein yield in seed after harvest and found significantly superior than the land configuration methods, 2 feet ridge and furrow and flat bed, however comparable with the land configuration method BBF.

\section{Effect of sulphur levels}

The highest application of $30 \mathrm{~kg} \mathrm{~S} \mathrm{ha}^{-1}$ recorded significantly the highest mean oil content $(18.27 \%)$, protein content $(43.23 \%)$, oil yield $\left(4.96 \mathrm{~kg} \mathrm{ha}^{-1}\right)$ and protein yield $(11.77 \mathrm{~kg}$ $\mathrm{ha}^{-1}$ ) in seed as compared to $10 \mathrm{~kg} \mathrm{ha}^{-1}$ and $00 \mathrm{~kg} \mathrm{ha}^{-1}$ sulphur levels, however on par with the application of sulphur @20 $\mathrm{kg} \mathrm{S} \mathrm{ha}{ }^{-1}$ after harvest. Mean oil content, protein content, oil yield and protein yield in seed increased with each increasing level of sulphur application. The high response of soybean was observed by the balanced application of $\mathrm{N}$ and $\mathrm{S}$. These nutrients involved in the biosynthesis of proteins and many other important biomolecules, a balanced application of $\mathrm{S}$ and $\mathrm{N}$ enhanced their use efficiency in crop plants. Maximum oil yield was obtained in rapeseed mustard only, when $\mathrm{S}$ and $\mathrm{N}$ applications were balanced Ahmad et al., (1998) ${ }^{[1]}$. As well as Gokhale et al., (2005) [6] recorded highest oil content (37.26\%) in soybean with application of $40 \mathrm{~kg} \mathrm{~S} \mathrm{ha}^{-1}$. Oil seed crops responses to liberal application of sulphur because it is involved in the synthesis of fatty acids and also increased protein quality through the synthesis of certain amino acids such as cystine, cysteine and methionine Havlin et al., (1999) [7]. The increase in protein content of soybean with increasing level of S was also reported by Kumawat et al., (2000) ${ }^{[11]}$.

\section{Effect of interaction}

The interaction effect between land configuration methods and sulphur methods were found to be non-significant in respect of oil \& protein content in seed. 
Table 3: Effect of land configuration methods and sulphur levels on quality of soybean after harvest

\begin{tabular}{|c|c|c|c|c|}
\hline Treatments & Oil content in seed $(\%)$ & Oil yield $\left(\mathrm{kg} \mathrm{ha}^{-1}\right)$ & Protein content in seed $(\%)$ & Protein yield $\left(\mathrm{kg} \mathrm{ha}^{-1}\right)$ \\
\hline \multicolumn{5}{|c|}{ Main Plot: land configurations } \\
\hline $\mathrm{I}_{1}$ - Flat Bed & 16.69 & 3.53 & 38.15 & 8.04 \\
\hline $\mathrm{I}_{2}$ - Broad Bed Furrow & 17.84 & 4.66 & 42.15 & 11.02 \\
\hline I3- Ridge and Furrow (2 feet) & 17.51 & 4.15 & 38.64 & 9.22 \\
\hline I4- Ridge and Furrow (3 feet)) & 18.67 & 4.97 & 42.41 & 11.33 \\
\hline S. EM \pm & 0.24 & 0.14 & 0.60 & 0.29 \\
\hline C. D. at $5 \%$ & 0.84 & 0.49 & 2.09 & 0.99 \\
\hline C. V.\% & 4.74 & 11.33 & 5.18 & 10.03 \\
\hline \multicolumn{5}{|c|}{ Sub Plot: Sulphur levels } \\
\hline $\mathrm{S}_{1}-00 \mathrm{Kg} \mathrm{S} \mathrm{ha} \mathrm{K}^{-1}$ & 16.97 & 3.51 & 37.06 & 7.63 \\
\hline $\mathrm{S}_{2}-10 \mathrm{Kg} \mathrm{S} \mathrm{ha}{ }^{-1}$ & 17.36 & 4.23 & 39.74 & 9.68 \\
\hline $\mathrm{S}_{3}-20 \mathrm{Kg} \mathrm{S} \mathrm{ha}^{-1}$ & 18.11 & 4.62 & 41.31 & 10.53 \\
\hline $\mathrm{S}_{3}-30 \mathrm{Kg} \mathrm{S} \mathrm{ha}^{-1}$ & 18.27 & 4.96 & 43.23 & 11.77 \\
\hline S. EM \pm & 0.24 & 0.15 & 0.65 & 0.35 \\
\hline C. D. at $5 \%$ & 0.70 & 0.44 & 1.91 & 1.01 \\
\hline C. V.\% & 4.73 & 12.16 & 5.62 & 12.15 \\
\hline \multicolumn{5}{|c|}{ Interaction: $\mathbf{I} \times \mathbf{S}$} \\
\hline S. EM \pm & 0.48 & 0.30 & 1.30 & 0.69 \\
\hline C. D. at $5 \%$ & NS & NS & NS & NS \\
\hline General mean & 17.68 & 4.33 & 40.34 & 9.90 \\
\hline
\end{tabular}

\section{Conclusion}

1. Among the soybean land configuration method viz., 3 feet ridge and furrow was suitable for Western Maharashtra region and would be recommended for better yield and quality.

2. The sulphur application @ $30 \mathrm{Kg} \mathrm{ha}^{-1}$ is beneficial for better yield and quality of soybean.

\section{References:}

1. Ahmad A, Abraham G, Gandotra N, Abrol YP, Abdin MZ. Interactive effect of nitrogen and sulphur on growth and yield of rapeseed-mustard (Brassica juncea L. Czern and Coss. and Brassica campestris L.). Journal of Agronomy and Crop Science 1988;181:193-199.

2. Arun Sharma.. Study the effect of sulphur and phosphorous with and without PSB inoculation on the yield attributes, yield and nutrient uptake of soybean. Journal of Progressive Agriculture 2011;2(2):41-43.

3. Balasubramaniyan P, Palaniappan SP. Principles and Practices of Agronomy 2012.

4. Devi KN. Response of soybean (Glycine max L. Merril) to sources and levels of phosphorus. Journal of Agriculture Science 2012;4:44-53.

5. Ganeshmurthy AN. Critical plant sulphur content and effect of sulphur application of grain and oil yield of rainfed soybean in Vertic Ustochrepts. Journal Indian Society of Soil Science 1996;44:290-294.

6. Gokhale DN, Kanade AG, Karanjikar PN, Patil VD. Effect of sources and levels of sulphur on seed yield, quality and sulphur uptake by soybean, (Glycine max L. Merrill) Journal of Oilseeds Res. 2005;22(1):192-193.

7. Havlin LJ, Beaton DJ, Tisjale LS, Nelson LW. Soil fertility and fertilizers. Prentice Hall of Indian 1999;6:319-346.

8. Hosmath JA, Babalad HB, Basavraj GT, Jahagirdar Shamrav, Patil RH, Agasimani SC. Sulphur nutrition in soybean (Glycine max L. Merril) in India. International Conference on Biological, Civil and Environmental Engineering (BCEE-2014) Dubai (UAE) 2014.

9. Hussain K, Islam M, Siddique MT, Hayat R, Mohsan S. Soybean growth and nitrogen fixation as affected by sulphur fertilization and inoculation under rainfed conditions in Pakistan. International Journal of Agriculture and Biology 2011;13(6):951-955.

10. Ingle MP, Malvi GC, Hadole SS, Padekar DG, Ingale AS. Effect of land configuration and nitrogen management on yield attributing character and yield of kharif soybean. Journal Soils and crops. 1999;9(1):34-36.

11. Kumawat SM, Dhakar LL, Maliwal PL. Effect of irrigation regimes and nitrogen on yield, oil content and nutrient uptake of soybean (Glycine max L. Merrill). Indian Journal of Agronomy 2000;45(2):361-366.

12. Lakpale R, Tripathi RS. Broad-bed furrow and ridge and furrow method of sowing under different seed rates of soybean (Glycine max L.) for high rainfall areas of Chhattisgarh plains. Soybean Research 2012;10:52-59.

13. Nangare MV. Performance of soybean varieties under different layouts. M.Sc. (Agri) Thesis, Mahatma Phule Krishi Vidyapeeth, Rahuri (M.H.), India 2015.

14. Panse VG, Sukhatme PV. Statistical methods for agricultural research workers. ICAR publication, New Delhi 1967.

15. Pasricha NS, Aulakh MS. Sulphur: An emerging defiecient nutrient. In plant nutrient needs, supply, efficiency and policy issues. National Academy of Agricultural Science, New Delhi 1996,265-282.

16. Thakur NS, Raghuwanshi RS, Sharma RS. Performance of soybean genotypes under different row spacings and seed rates in medium black soils of Satpura plateau. Research on Crop 2003;4(3):313-316. 